\title{
REINVESTIGATING CARBONIFEROUS "ACTINOMYCETES": AUTHIGENIC FORMATION OF BIOMIMETIC CARBONATES PROVIDES INSIGHT INTO EARLY DIAGENESIS OF PERMINERALIZED PLANTS
}

\author{
ASHLEY A. KLYMIUK, ${ }^{1 *}$ CARLA J. HARPER,${ }^{1}$ DAVID S. MOORE, ${ }^{2}$ EDITH L. TAYLOR,${ }^{1}$ THOMAS N. TAYLOR, ${ }^{1}$ and \\ MICHAEL KRINGS 1,3 \\ ${ }^{1}$ University of Kansas, Department of Ecology and Evolutionary Biology, Lawrence, Kansas 66045-7534, USA, klymiuk@ku.edu, charper@ku.edu, etaylor@ku.edu, \\ tntaylor@ku.edu; ${ }^{2}$ University of Kansas, Center for Research and Graduate Studies, Microscopy \& Analytical Imaging Center, Lawrence, Kansas 66045-7534, USA, \\ dsmn@ku.edu; ${ }^{3}$ Department für Geo- und Umweltwissenschaften, Paläontologie und Geobiologie, Ludwig-Maximilians-Universität, and Bayerische Staatssammlung für \\ Paläontologie und Geologie,80333 Munich, Germany,m.krings@lrz.uni-muenchen.de
}

\begin{abstract}
Paleoecological interactions among fossil microorganisms have garnered significant interest within the paleobotanical community; however, an understanding of the early diagenesis of associated plant material is of critical importance when assessing putative body fossils of fungi and bacteria. Structures preserved within permineralized petioles of the Carboniferous fern Botryopteris tridentata Felix (Scott) have been interpreted as the earliest remains of Actinobacteria found in association with vascular plants, but re-examination of the specimens indicates instead that these biomimetic structures (BMS) are authigenic carbonate minerals. Using spinning disk confocal microscopy, we generated monochromatic luminescence maps of BMS found within the phloem cells of Botryopteris. Luminescence was captured at wavelengths of $665 \mathrm{~nm}$, consistent with an interpretation of these structures as disordered dolomites, an inference subsequently corroborated with energy-dispersive X-ray spectrometry (SEM-EDS). The presence of high-magnesium carbonates within Botryopteris is suggestive of an early anaerobic stage of plant tissue degradation characterized by metabolic activities of sulfate-reducing bacteria. Anaerobic biodegradation may also have been performed by chytridiomycetes, and we interpret larger (5-8 $\mu \mathrm{m})$ unicells found within the specimens as fossils of chytrid zoosporangia. Understanding microbial contribution to the early diagenesis of plants preserved within calcium carbonate concretions (coal balls) is dependent upon both characterizing diversity of microbial communities within fossil plants, and elucidating the geomicrobiological parameters of mineralization. As such, this study underscores the necessity of integrating geomicrobiology with plant taphonomy in investigations of the microbial component of ancient ecosystems.
\end{abstract}

\section{INTRODUCTION}

For nearly half a century, microbial fossils have been the focus of intense interest among researchers who have attempted both to understand the early conditions under which life evolved, and to characterize the fossil record of bacteria (e.g., Barghoorn and Tyler, 1965; Barghoorn and Schopf, 1966; Knoll, 1982; Schopf, 1993; Wacey et al., 2011). As a result, we are moving toward a more sophisticated understanding of hydrogeochemical conditions under which bacteria may fossilize (e.g., Van Lith et al., 2003; Lalonde et al., 2005; GarcíaVallès et al., 2008; Dupraz et al., 2009), and some of the abiogenic processes that can mimic bacterial morphologies (e.g., Hofmann, 1972; García-Ruiz, 1994; Lowe, 1994; Grotzinger and Rothman, 1996; García-Ruiz et al., 2002, 2003; McLoughlin et al., 2008). As living

\footnotetext{
* Corresponding author.

Published Online: February 2013
}

Copyright (C) 2013, SEPM (Society for Sedimentary Geology) hosts or decaying substrates, plant tissues constitute a physical and biochemical landscape in which distinct microbial ecosystems have evolved (Bianciotto et al., 1996; Lodwig et al., 2003; Kotsyurbenko et al. 2004; Bouwmeester et al., 2007). The interactions between microbes and vascular plants have a deep evolutionary history (e.g., Pirozynski and Malloch, 1975; Bateman et al., 1998; Tomescu et al., 2006; Wang et al., 2010), and understanding how such interactions have developed and changed throughout the Phanerozoic is a rapidly expanding field of paleobotanical research (Beimforde et al., 2011; Massini et al., 2012). A reinvestigation of structures originally interpreted as the earliest representatives of Actinomycetes (Actinobacteria) in association with vascular plants (Smoot and Taylor, 1983) underscores the necessity of approaching some putative microbes with an understanding of early diagenetic processes that can produce biomimetic structures (BMS).

The actinomycetes are physiologically diverse, high G-C (guaninecytosine) content Gram-positive bacteria (Stackebrandt and Woese, 1981; Embley and Stackebrandt, 1994; Fox and Stackebrandt, 1987), many of which occur as branching septate filaments that are morphologically reminiscent of fungal hyphae, although generally much smaller (Waksman, 1950; Lechevalier and Lechevalier, 1967). Actinomycetes are known to play a vital role in the ecology of plant communities. Within the rhizosphere, they function as saprobes (Goodfellow, 1983; Jaatinen et al., 2008; Aliasgharzad et al., 2010), and many also have intimate associations with vascular plants, such as the nitrogen-fixing mutualist Frankia (Reddell and Bowen, 1985; Sellstedt et al., 1986). Endophytically, some actinomycetes occur as plant pathogens or parasites, but most have a commensal relationship with their hosts, conferring resistance to pathogenic fungi (Goodfellow, 1983; Doumbou et al., 2001, Taechowisan et al., 2003; Conn et al., 2008). Understanding the evolution of such mutualistic associations may offer insight into the early evolution of terrestrial plants, and may also allow us to better conceptualize ecological constraints within ancient plant communities.

At present, however, the fossil record for actinomycetes is sparse, and predominantly Cenozoic (Waggoner, 1993, 1994a, 1994b; Wilkinson, 2003; Fostowicz-Frelik and Frelik, 2010; Poinar, 2011; Saint Martin et al., 2012). The oldest known records of filamentous bacteria in association with plant tissue are specimens described from within threedimensionally permineralized cells of a Pennsylvanian fern, Botryopteris tridentata (Felix) Scott (Smoot and Taylor, 1983). A reexamination of these specimens, however, demonstrates there is little support for considering them actinomycete bacteria. Instead, we suggest that these structures are authigenic carbonate minerals, formed in conjunction with the anaerobic degradation of plant cell material.

While there is no evidence of actinomycete remains within these Carboniferous specimens, the Botryopteris tissue is not devoid of microbial fossils, and we reinterpret larger spherical unicells (Smoot and Taylor, 1983, fig. 8) as chytridiomycete zoosporangia. Chytrids 
(Chytridiomycota) are morphologically simple fungi (James et al., 2006a, 2006b), that occupy environmental niches in polar to tropical terrestrial, freshwater, estuarine, and marine ecosystems (Powell, 1993; Barr, 2001; Hibbett et al., 2007), where they function as saprotrophs, bioeroders, parasites, mutualists, and pathogens (Karling, 1977; Gleason et al., 2008; Kilpatrick et al., 2010). Chytrids exhibit a plesiomorphic form of reproduction where motile, flagellated spores (zoospores) are borne in larger, saclike structures termed zoosporangia (James et al., 2006a), and representatives of these life cycle stages are well known in the chytrid fossil record (e.g., Millay and Taylor, 1978; Taylor et al., 1992; Trewin et al., 2003; Krings et al., 2009a, 2009b; Massini et al., 2012). The body fossils we interpret as zoosporangia provide additional evidence for the role of these fungi as saprotrophs within ancient environments.

The microbial paleoecology of plant tissues is a field of inquiry that is gaining significant momentum, and these studies continue to offer insight into the interactions between microbes and the plants that both host them and act as substrates (e.g., Taylor and Krings, 2010; Krings et al., 2011, 2012; Harper et al., 2012). As has been indicated by other studies (Buick et al., 1990; Van Zuilen et al., 2002; Brasier et al., 2005; Schopf, 2004), our reinvestigation of putative actinomycete remains demonstrates the necessity of appreciating abiogenic processes that can produce microscopic pseudofossils. In this study, we illustrate that critical examination of such structures can reveal features suggestive of abiogenicity, and utilize both monochromatic luminescence mapping and energy-dispersive X-ray spectrometry (SEM-EDS) to characterize their mineralogy. In addition to suggesting methods by which to identify legitimate microbial body fossils from biomimetic carbonates, our results indicate that comprehensive investigation of degrading plant tissue in a geomicrobiological context will further our understanding of taphonomic processes that lead to both information loss and preservation in the paleobotanical record.

\section{MATERIAL AND METHODS}

Material investigated in this study occurs within calcium carbonate concretions, commonly known as coal balls, which were collected from the Lewis Creek locality $\left(37^{\circ} 0^{\prime} 0.35^{\prime \prime} \mathrm{N}, 83^{\circ} 17^{\prime} 34.39^{\prime \prime} \mathrm{W}\right)$ of Leslie County, Kentucky, United States. The concretions, within which plant remains are anatomically preserved, are associated with the Copland (Taylor) coal (Smoot and Taylor, 1983). The Copland coal is considered the uppermost unit of the Moscovian (Middle Pennsylvanian) Hyden Formation (Fm) of the Breathitt Group (Chesnut, 1996; Greb et al., 1999), and is overlain by shales of the Magoffin Member of the Four Corners Fm (Schopf, 1961; Smoot and Taylor, 1983; Chesnut, 1996).

The specimens were originally prepared using the cellulose acetate peel technique (Joy et al., 1956), and resultant sections were mounted on microscope slides using xylene-soluble Harleco (EMD Millipore) Synthetic Resin (Smoot and Taylor, 1983). Additional material was prepared for scanning electron microscopy (SEM) by etching portions of the phloem tissue (Smoot, 1979), and the original SEM micrographs are refigured in this reinvestigation. In addition to photomicrographing specimens from slides prepared by Smoot and Taylor (1983), we also mounted several acetate peels for SEM-EDS analysis; these comprised serial sections \#4, \#13, \#19, \#25 from specimen 6809 D3 side. All specimens and slides are deposited in the Paleobotanical Collections, Natural History Museum and Biodiversity Institute, University of Kansas, (Lawrence, Kansas). Slide accessions comprise 7523, 7525, 7532, 7554, 7556, 7563, and 7566, and were made from accessioned specimens $6592 \mathrm{C}$ top 7, $6592 \mathrm{D}$ side 11, 6592 D side 15, 6809 D3 side B 22, 6809 D3 side B 29, 6809 D3 side B 43, and 6809 D3 side B 50. In the course of our investigations, we also reexamined specimens originally figured as mycorrhiza (Andrews and Lenz, 1943, fig. 6), using slides from the Henry N. Andrews collection, deposited at the George Safford Torrey Herbarium, Department of Ecology and Evolutionary Biology, Storrs, Connecticut.
All digital images were captured with a Leica DC500 CCD attached to a Leica DM5000B transmitted-light compound microscope and minimally processed using Adobe Photoshop CS5 v12.1. Multiple photomicrographs of the same specimen, taken at different focal planes, were compiled (after Bercovici et al., 2009) to produce the composite images of chytrid body fossils. Focal stacking was performed in Adobe Photoshop CS4 v11.0.2 by erasing specific areas to reveal three dimensionality of the specimen as is visible under transmitted light. Measurements were performed in ImageJ 1.43u (W.S. Rasband, U.S. National Institutes of Health, Bethesda; Abràmoff et al., 2004).

Spinning disk confocal microscopy was performed using an Olympus IX71 microscope equipped with a Yokagawa CSU10 spinning disk confocal illumination system. Excitation was performed with a $641 \mathrm{~nm}$ Coherent solid-state laser. Emission was collected using a Semrock longpass $665 \mathrm{~nm}$ filter, and image capture was performed with a Hamamatsu $512 \times 512$ back-thinned electron multiplying CCD (quantum efficiency $\sim 94 \%$ ). Images were captured using Slidebook 5.0 (Intelligent Imaging Innovations, Denver, Colorado) and were pseudocolored green with ImageJ $1.45 \mathrm{~s}$, to optimize visibility.

Elemental composition of structures of interest was assessed using SEM-EDS. Select specimens, as previously indicated, were coated with $15 \mathrm{~nm} \mathrm{Au}$, using a Quorum EMS 150T ES. Scanning electron microscopy was performed using a Carl Zeiss LEO 1550 Field Emission Scanning Electron Microscope with an Everhart-Thornley detector. Spectrometry was conducted at $15 \mathrm{kV}$, and spectra were collected with an EDAX SiLi detector, using the collection package Genesis (EDAX Inc., Mahwah, New Jersey, United States).

\section{RESULTS}

Biomimetic Structures.-Smoot and Taylor (1983, p. 2252) originally described inclusions within some petioles of the Pennsylvanian fern Botryopteris tridentata (Figs. 1A-B) as "smooth, knobby filaments and spheres." They suggested that some (Figs. 1B-E) represent body fossils of filamentous bacteria most similar to extant actinomycetes, whereas others are dried mucilage or cytoplasm (Figs. $1 \mathrm{~F}-\mathrm{L}$ ). The inclusions are distributed within cells interpreted as phloem mucilage cells (Fig. 1A); cells that contain inclusions with a so-called bacterial morphology are adjacent to those in which acicular or amorphous inclusions occur (Figs. 1A-B).

The $0.5-1.0 \mu \mathrm{m}$ sporelike structures are spheroidal, but are neither isodiametric nor consistent in size (Figs. 1C-E). Furthermore, by shifting the focal plane, the so-called filaments are revealed as dense aggregates of spheroids (Figs. 1D-E). Additionally, the spheroidal structures occur as interwoven lattices, a morphology that is inconsistent with the manner in which the coccoidal spores of extant actinomycetes are borne (see Supplementary Data ${ }^{1}$ ). Smoot and Taylor (1983) originally interpreted reticulate aggregations of acicular precipitates (Figs. 1F-L) as dried mucilage or coagulated cytoplasm, but these structures grade into pyriform and spheroidal morphologies (Figs. $1 \mathrm{G}-\mathrm{H}$ ), consistent with those interpreted as bacterial body fossils. Moreover, patterns within the reticulate aggregates which superficially resemble septa (Fig. 1J-K, arrows) are in fact fractures (Figs. 1J-L). Some cells also contain larger, 2.0-4.0 $\mu \mathrm{m}$, spheroidal or oblate structures (Fig. 1M), which are irregular, amorphous, translucent aggregations that are in close proximity with both acicular and spheroidal structures (Fig. 1M, arrows).

Laser excitation of three types of inclusions (Figs. 2A-C) in Botryopteris resulted in emission that was captured at $665 \mathrm{~nm}$; the monochromatic map of luminescence observed with spinning disk confocal illumination (Figs. 2D-F) indicates that despite very differing morphologies, these biomimetic structures contain similar activating and sensitizing cations. Luminescence was not observed at wavelengths typically associated with organic polymers or calcium carbonate, and could not be detected using standard epifluorescence techniques.

\footnotetext{
${ }^{1}$ www.palaios.ku.edu
} 

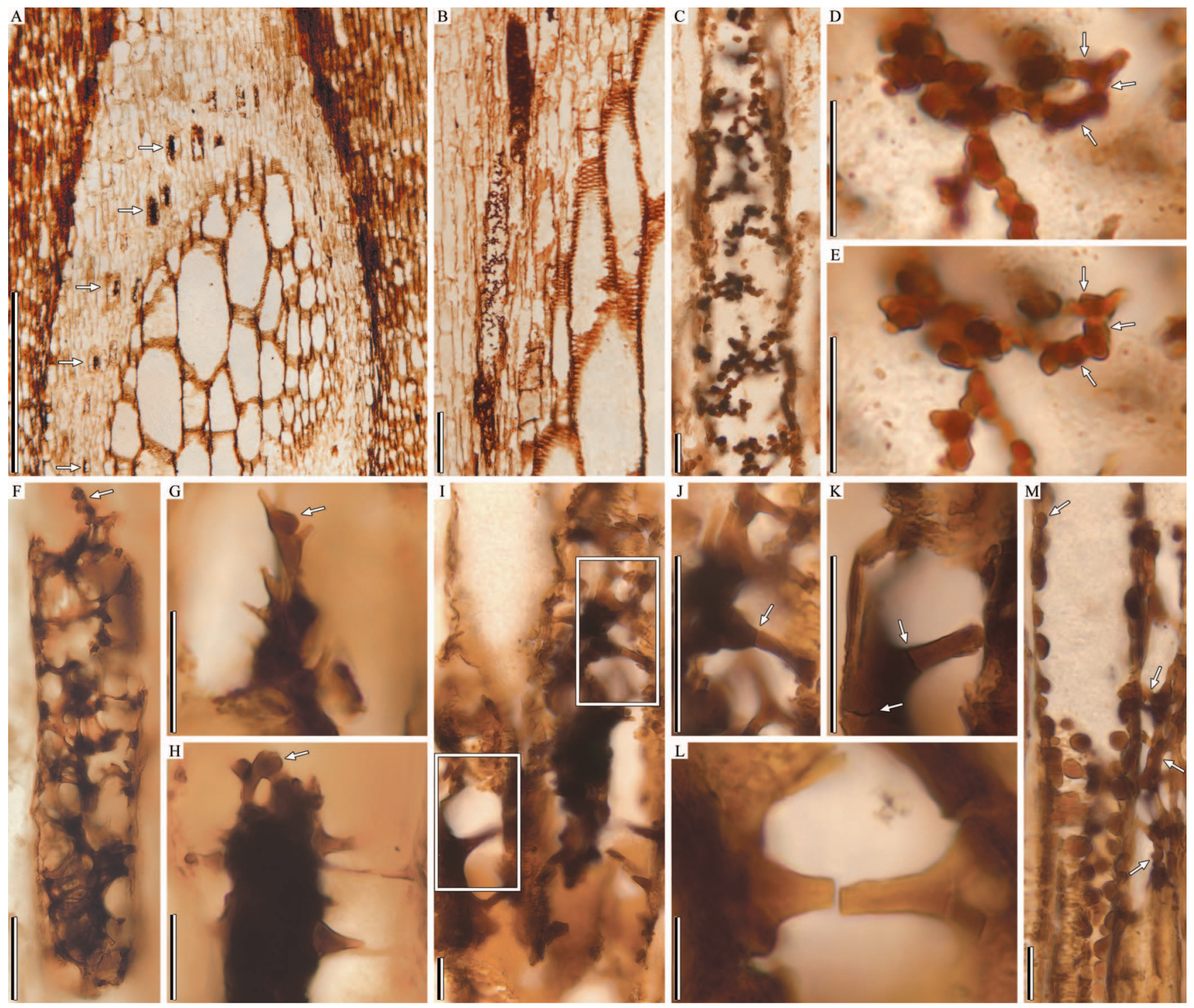

FIGURE 1-Photomicrographs of biomimetic structures (BMS) preserved within phloem mucilage cells of Botryopteris tridentata. A) Oblique transverse section of Botryopteris tridentata petiole; arrows = BMS, Slide No. 7523, scale $500 \mu \mathrm{m}$. B) BMS originally interpreted as actinobacteria; Slide No. 7563 , scale 100 $\mu \mathrm{m}$. C) Higher magnification of BMS originally interpreted as actinobacteria; Slide No. 7563. D-E) Spheroidal BMS viewed in different focal planes to demonstrate optical illusion of filament-like morphology. Note that putative filaments are composed of aggregated spheroids (arrows); Slide No. 7556. F-H) Acicular aggregated BMS originally interpreted as dried mucilage or protoplasm. Arrows denote spheroids similar to the actinobacteria-like BMS; F = Slide No. $7525, \mathrm{G}-\mathrm{H}=$ Slide No. 7523 . I) Acicular BMS with features resembling septa. Upper box $=$ Fig. J; lower box $=$ Fig. K; Slide No. 7556. J-K ) Magnification of putative septa in acicular BMS demonstrates that these features are fractures (arrows); Slide No. 7556. L) Fractured BMS; Slide No. 7523. M) Spheroidal to oblate BMS, in association with spheroidal (upper- and lowermost arrows) and acicular BMS (medial arrows); Slide No. 7554, scales for $\mathrm{C}-\mathrm{M}=10 \mu \mathrm{m}$.

Elemental composition of inclusions was characterized with comparison to plant cell walls and intracellular calcium carbonate cement (Fig. 3). Calcium (Ca) and magnesium $(\mathrm{Mg})$ are present in both cell walls and cement, although the spectral signature for $\mathrm{Ca}$ is more robust; furthermore $\mathrm{Ca}$ is highly represented within the intracellular cement, in accordance with expectations (Figs. 3A-B). Typical spectra associated with inclusions have peaks for both $\mathrm{Ca}$ and $\mathrm{Mg}$ that are of similar magnitude (Fig. 3C). Iron (Fe) was not observed in the plant cell walls, but a slight peak at $\sim 6.04 \mathrm{keV}$ was observed in intracellular cement (Fig. 3B), consistent with the K $\alpha$ shell of Fe. Within inclusions, spectral peaks concordant with both the $\mathrm{L} \alpha$ and $\mathrm{K} \alpha$ electron shells of $\mathrm{Fe}$ are evident (Fig. 3C). Iron sulfide, or pyrite, is also present within some of the Botryopteris tissues (Fig. 4). It occurs as small, 1-2 $\mu \mathrm{m}$ euhedral crystals that are typically surrounded by a rind of translucent mineral (Fig. 4, inset), containing both $\mathrm{Ca}$ and $\mathrm{Mg}$.
Cell Wall Microstructure.-Slender, scalalike protrusions, $1 \mu \mathrm{m}$ wide, occur in the intercellular spaces between some phloem cells when viewed in longitudinal section (Fig. 5A). The projections are continuous with the cell walls, which may be shrunken into the lumen (Fig. 5B). Where projections do not extend entirely across the intercellular space, they may be terminated by spheroidal masses, some of which have a bilobed, or slightly dumbbell-shaped morphology (Fig. 5C, arrow). Mineral halos may be observed around some of the projections (Fig. 5B, inset).

Microbial Body Fossils.-Smoot and Taylor (1983, fig. 8) originally figured large (5.0-8.0 $\mu \mathrm{m}$ diameter) spherical structures within phloem mucilage cells of Botryopteris (Figs. 6A-B), but did not discuss their possible affinities. Reexamination of these fossils indicates that they represent the remains of chytridiomycete zoosporangia. Each has a single pore, $1.0-2.0 \mu \mathrm{m}$ in diameter (Fig. 6B), and there are minute, 

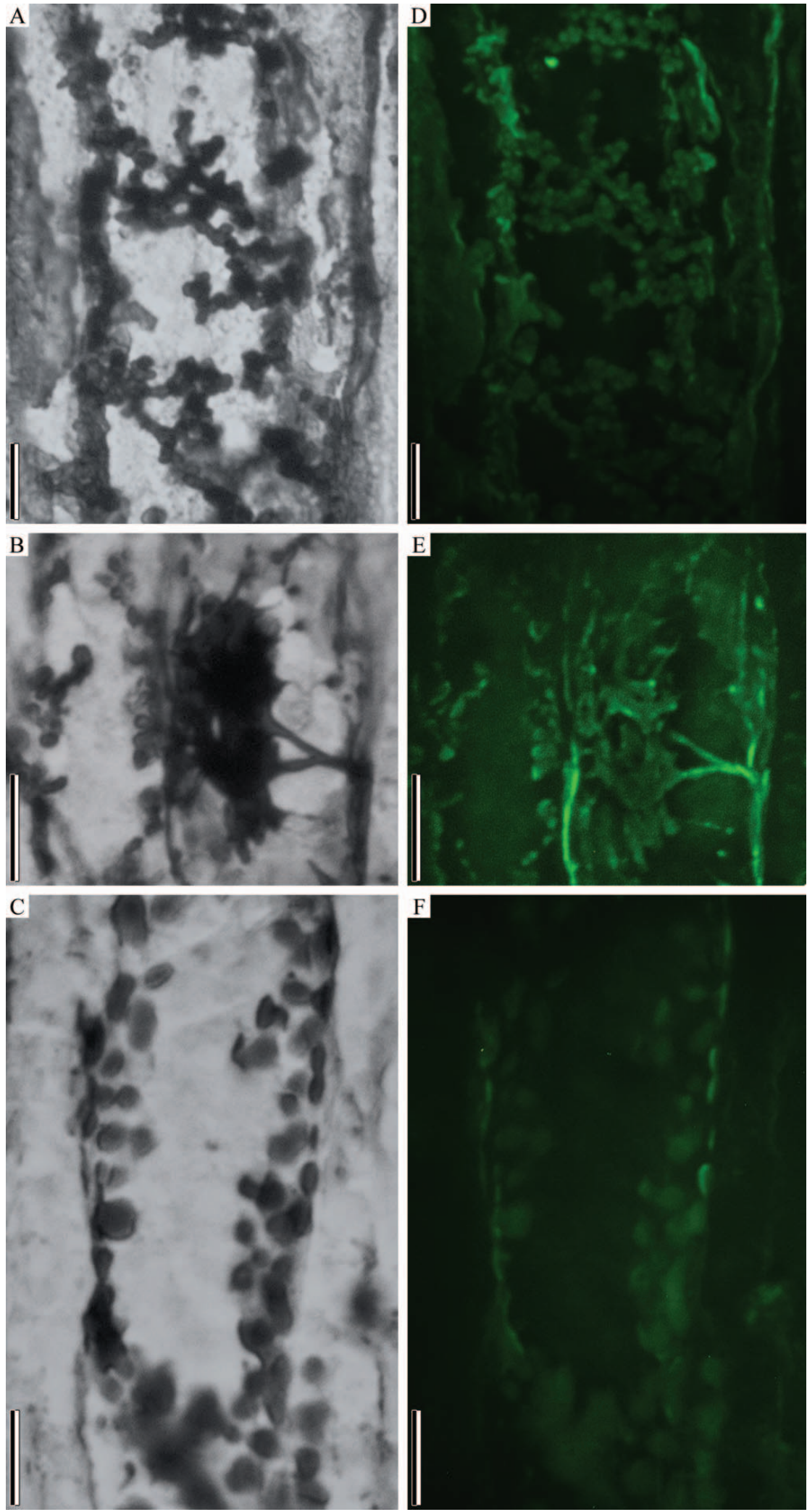

FIGURE 2-Monochromatic mapping of luminescence in biomimetic structures. A-C) Bright field image of BMS corresponding to monochromatic maps of luminescence D-F) Monochromatic maps of emission spectra captured at $665 \mathrm{~nm}$. A, D = Slide No. 7563; B, E = Slide No. 7523; C, F = Slide No. 7523 , all scales $15 \mu \mathrm{m}$.

amorphous precipitates encrusting the exterior surface of the fungal cell wall. Individual precipitates vary significantly in size, and they are continuous with similar subspheroidal precipitates lining the plant cell tissue beneath the fungal remains (Fig. 6B). The discovery of additional fungal remains, namely a cluster of unicells in close association with a fern spore adjacent to the Botryopteris petiole (Fig. 6C), provides additional features not observed in the original study. These unicells are identical to those figured by Smoot and Taylor (1983); they range in 

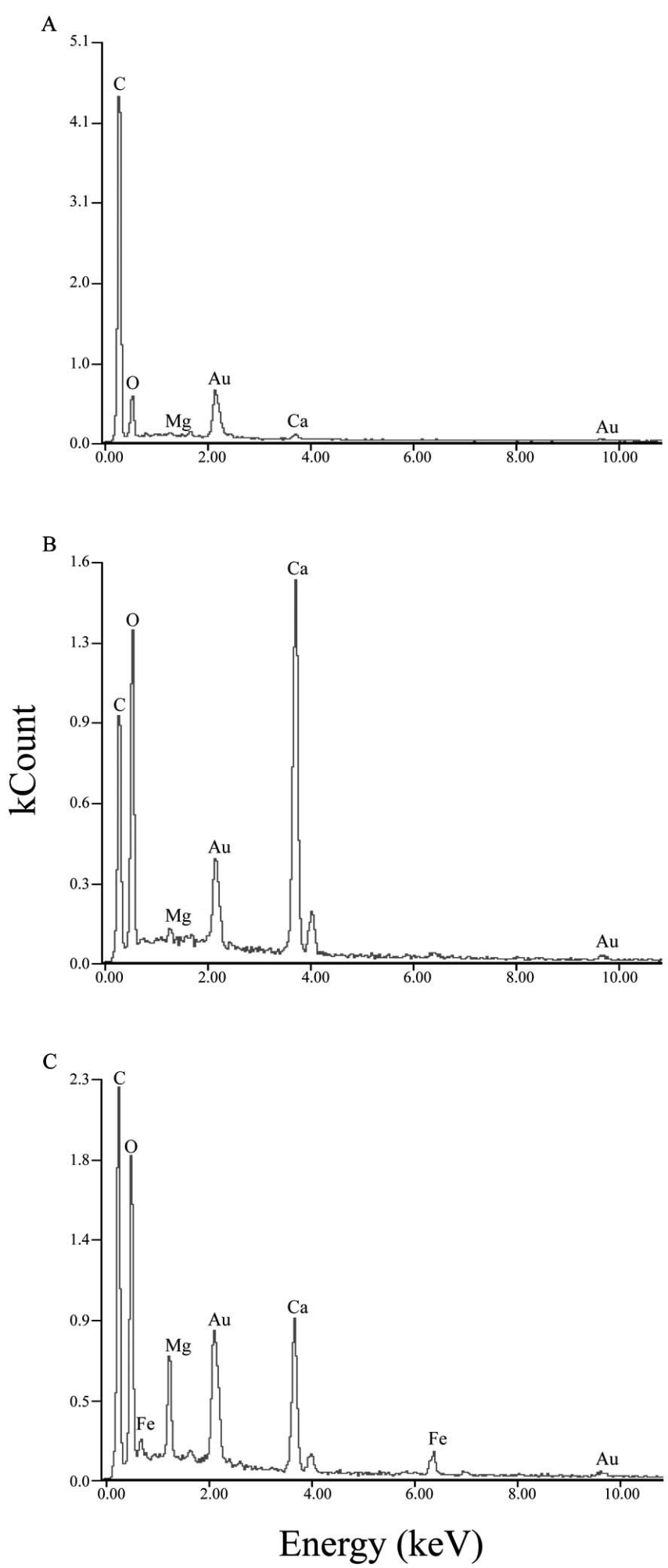

FIGURE 3-Representative spectra from scanning electron microscope energydispersive X-ray spectrometry (SEM-EDS) of cellulose acetate peels of Botryopteris tridentata. A) Cell wall. B) Intracellular cement. C) Spheroidal biomimetic structure.

diameter from 5-8 $\mu \mathrm{m}$, and a faint collar surrounds the $1.0 \mu \mathrm{m}$ diameter discharge pore (Fig. 6D). Additionally, an operculum is visible on a single zoosporangium (Fig. $6 \mathrm{D}$, upper arrow), and a $0.7-\mu \mathrm{m}$-diameter zoospore is present near a discharge pore (Fig. 6D, lower arrow).

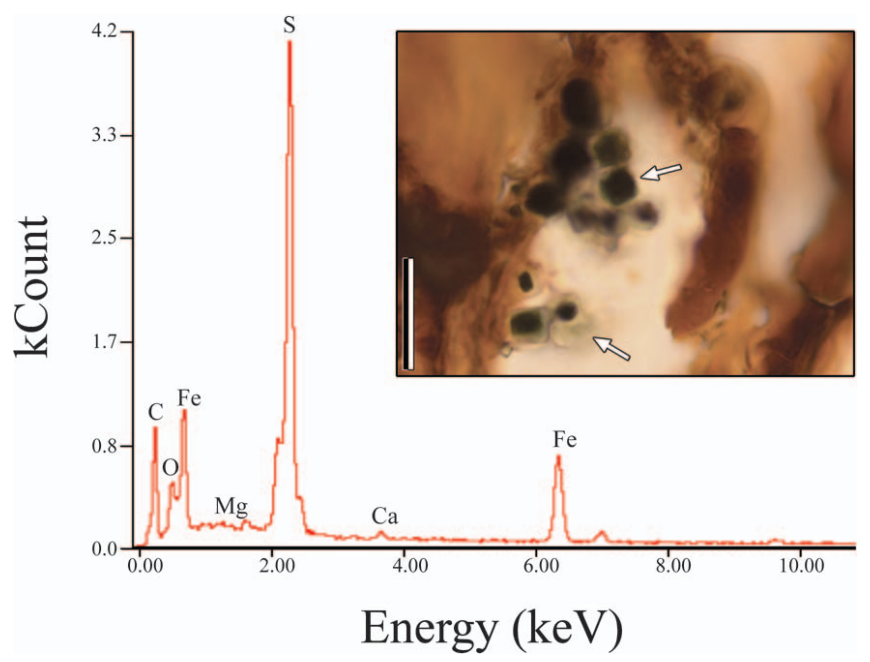

FIGURE 4-Representative SEM-EDS spectrum of pyrite within Botryopteris tridentata. Inset, photomicrograph of euhedral pyrite (upper arrow) encrusted with carbonate minerals (lower arrow); Slide No. 7563. Scale $10 \mu \mathrm{m}$.

\section{DISCUSSION}

Structures do not Represent Actinomycetes.-Actinomycetes are filamentous bacteria, the taxonomic affinities of which were uncertain prior to comparative approaches employing $16 \mathrm{~S}$ rRNA, owing to similarities between their morphology and colonial development, with that of the anamorphic phases of some true fungi (Waksman, 1950; Stackebrandt and Woese, 1981; Fox and Stackebrandt, 1987). Actinomycetes are now classified within Actinomycetales, the largest of five orders comprising the phylum Actinobacteria, which is sister to low G-C, Gram-positive bacteria (Embley and Stackebrandt, 1994; Stackebrandt et al., 1997; Zhi et al., 2009). Actinomycete colonies grow via the production of dense vegetative thalli or so-called substrate mycelia, with chains of spores produced via fragmentation of so-called aerial hyphae (Lechevalier and Lechevalier, 1967). Almost all actinobacteria have coccoidal or bacilloid spores and branching filaments that are $0.5-1.0 \mu \mathrm{m}$ in diameter (Lechevalier and Lechevalier, 1967; Goodfellow, 1983; Supplementary Data ${ }^{1}$ ). In extant actinomycetes, filament morphology can vary greatly, ranging from straight, flexuose, or fascicled to mono- and biverticillate; these latter forms may be further elaborated by the presence or absence of spirals, loops, and hooks (Lawton et al., 1989). The shape and arrangement of aerial filaments are commonly utilized in identification of actinobacteria (Hunter-Ceverja and Eveleigh, 1990).

Morphologically, the Carboniferous structures described by Smoot and Taylor (1983) are similar to extant actinomycetes in terms of the size of individual so-called coccoid elements (see Supplementary Data ${ }^{1}$ ). By contrast, structures preserved within the Botryopteris phloem lack filaments entirely; structures previously interpreted as filaments are in fact aggregates of spheroids. Although of similar size to coccoid spores, these spheroids are neither isodiametric, nor consistent in size. Furthermore, as spore production is most frequently accomplished through septation of aerial filaments (Lechevalier and Lechevalier, 1967), the latticelike morphology of the Carboniferous structures is problematic to an interpretation of these structures as so-called sporulated actinobacterial colonies, as no extant actinomycetes produce interwoven filaments (Supplementary Data ${ }^{1}$ ).

These Carboniferous structures likewise do not resemble other fossils that have been ascribed to Actinobacteria. Although these bacteria are thought to be exceptionally ancient (Embley and Stackebrandt, 1994; Ventura et al., 2007), their fossil record is sparse. Most body fossils of actinomycetes have been described from amber (Girard and Adl, 2011). These include: coccoid spores borne on substrate filaments with simple 

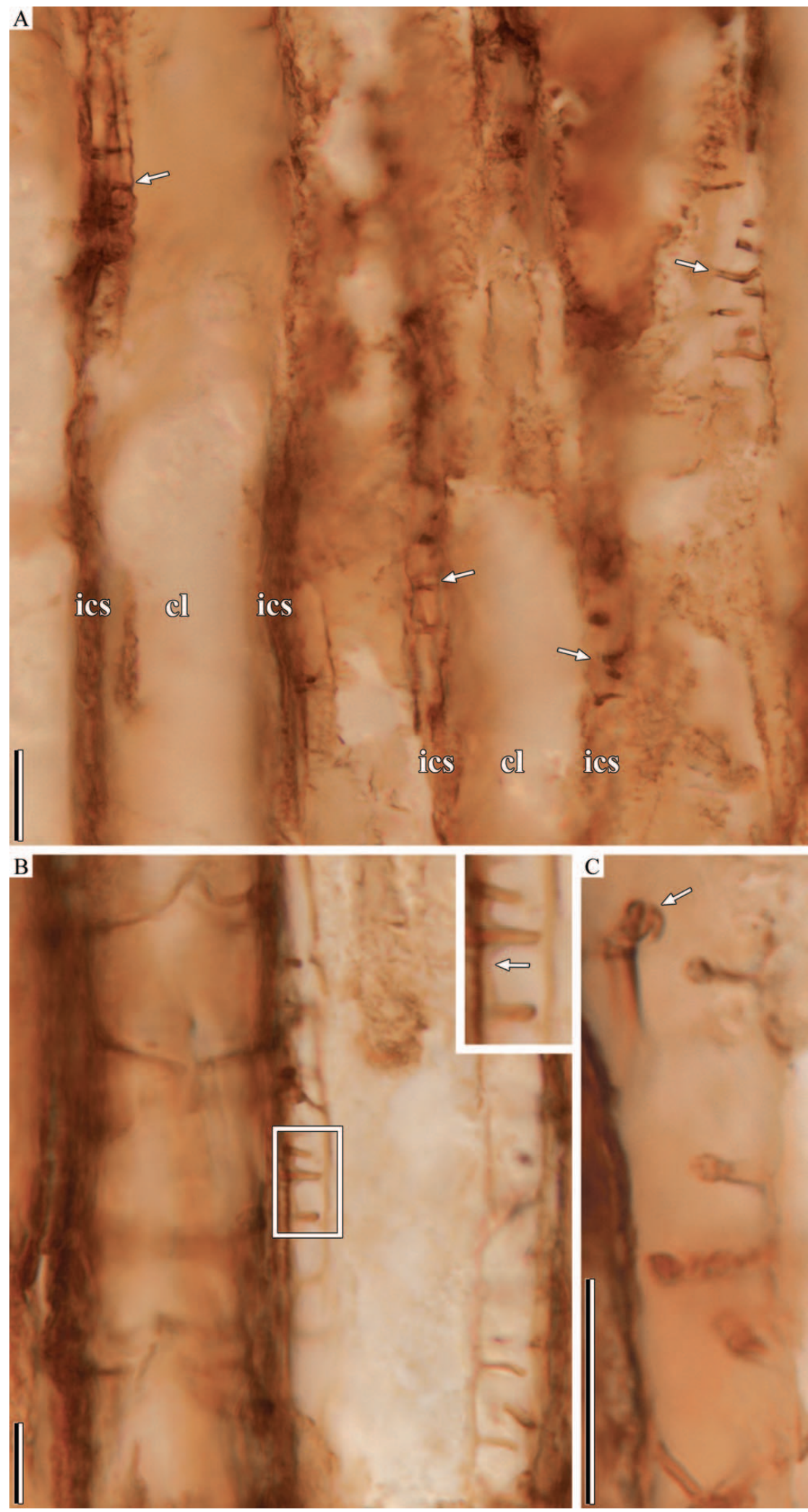

FIGURE 5-Photomicrographs of microstructural components of degraded phloem cells. A) Scala-like structures (arrows), interpreted as intercellular pectic protuberances (IPP), cl = cell lumen, ics = intercellular space; Slide No. 7523. B) Distribution of IPP in degraded middle lamella of mucilage cell (right) adjacent to phloem parenchyma cells (left). Magnification (inset) shows a mineral halo surrounding some IPP (arrow); Slide No. 7523. C) IPP with terminal masses morphologically similar to spheroidal BMS (arrow); Slide No. 7523, all scales $10 \mu \mathrm{m}$. 

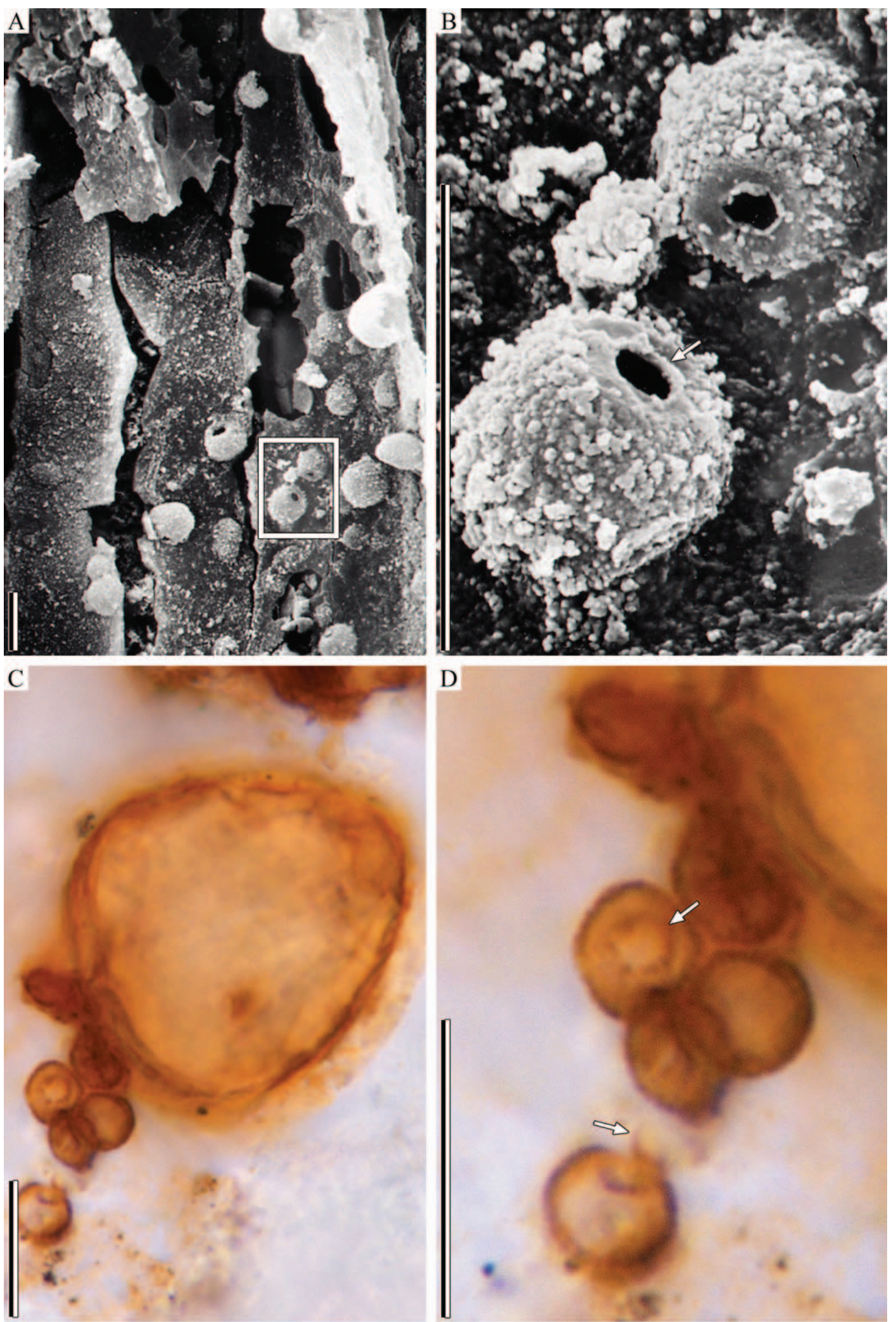

FIGURE 6-Microbial body fossils associated with Botryopteris tridentata. A) Reimaged SEM micrograph of zoosporangia in degraded phloem cells; Box = Fig. 3B B) Magnification of Figure 3A. Note collar surrounding pore (arrow) and mineral precipitates on cell surfaces. C) Photomicrograph of zoosporangia clustered adjacent to fern spore near Botryopteris petiole; Slide No. 7523. D) Magnification of clustered cells. Note operculum (upper arrow) and discharged zoospore (bottom arrow); Slide No. 7523, all scales $10 \mu \mathrm{m}$. 
branching, described from fecal pellets of beetles preserved in Oligocene-Miocene Dominican amber (Poinar, 2011); 1.0-2.0 $\mu \mathrm{m}$ coccoid spores from Eocene amber from Washington State (Waggoner,

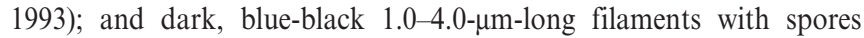
$1.0 \mu \mathrm{m}$ in diameter that are preserved in Eocene-Oligocene Dominican amber (Waggoner, 1994a). Older records include filaments up to $6.0 \mu \mathrm{m}$ long, with $1.0 \mu \mathrm{m}$ coccoid spores, described from Cretaceous amber, where they occur in association with other prokaryotes (Waggoner, 1994b; Saint Martin et al., 2012). The Carboniferous structures described by Smoot and Taylor (1983) were thought to have been the earliest record of actinomycetes in association with vascular plant tissue. As these structures closely resemble neither extant Actinobacteria, nor any of the known fossil actinomycetes (all of which exhibit both filaments, and spores, the latter of which are of uniform diameter and morphology within a specimen), we henceforth refer to them as biomimetic structures (BMS). Thus, a streptomycetelike actinomycete from the Eocene (Wilkinson, 2003) can now be said to constitute the oldest evidence of Actinobacteria in direct association with plant tissues.

The spheroidal BMS originally interpreted as actinomycetes are in close spatial association with acicular to amorphous structures that Smoot and Taylor (1983) interpreted as dried mucilage or cytoplasm (Smoot and Taylor, 1983). These stalactitic, translucent precipitates can form dense meshes similar to the spheroidal BMS (i.e., Fig. 1F), and in some cases, those that have a filamentous morphology appear to be septate. Close examination, however, reveals that putative septa are fractures ergo these structures are also merely biomimetic. Additionally, the fractures indicate that the substance these BMS are composed of was frangible prior to the permineralization of surrounding plant cells. Because subbotryoidal and spheroidal so-called sporelike masses are sometimes continuous with acicular BMS (i.e., Figs. $1 \mathrm{G}-\mathrm{H}$ ), and filamentlike BMS may be found in proximity to larger, oblate or amorphous structures, it is likely that all are composed of the same substance, which we suggest is an authigenic carbonate mineral.

Compositional Characterization of the Biomimetic Structures.-Despite their differing morphologies, the BMS preserved within these Botryopteris specimens appear to be composed of the same substance, as evidenced by similarities in luminescence (Fig. 2). Luminescence, inclusive of both fluorescence and phosphorescence, is a well-known feature of some organic compounds and many minerals. Luminescence occurs when the electrons of specific trace dopants within the crystal lattice have been excited to a higher energy level, and release a photon upon relaxation to a lower energy state (Marfunin, 1979; Gaft et al., 2005). Many of these activator dopants have characteristic emission spectra that can aid in identification of minerals (Gaft et al., 2005; McRae and Wilson, 2008). The most common activators are the transition metals $\mathrm{Mn}^{2+}, \mathrm{Mn}^{4+}, \mathrm{Sn}^{2+}, \mathrm{Pb}^{2+}$, and $\mathrm{Fe}^{3+}$ (Gorobets and Rogojine, 2002; Götze, 2002). While several rare earth elements can act as activators (e.g., Marfunin, 1979; Machel and Burton, 1991), luminescence in carbonates is most often attributed to $\mathrm{Mn}^{2+}$ cations, as they easily substitute for $\mathrm{Ca}^{2+}$ and $\mathrm{Mg}^{2+}$ cations, resulting in emission within red wavelengths (Waychunus, 1988; El Ali et al., 1993; Götze, 2002).

Where $\mathrm{Mn}^{2+}$ has replaced $\mathrm{Mg}^{2+}$ in dolomite, $\mathrm{Ca}(\mathrm{Mg}) \mathrm{CO}_{3}$, emission spectra peak at $661 \mathrm{~nm}$ (McRae and Wilson, 2008); it is therefore likely that luminescence observed in these BMS results from interactions between $\mathrm{Mn}^{2+}$ and sensitizer dopants in a disordered dolomitic mineral species. The intensity of emission was low, however, such that the BMS appeared nonluminescent using standard epifluorescence microscopy techniques. Although luminescence quenching likely resulted from the presence of $\mathrm{Fe}^{2+}$ cations, a variety of factors can result in nonradiative decay, including imperfections in crystal lattice (Marfunin, 1979; Gaft et al., 2005). The interactions between quenching dopants, sensitizers, and lattice structure complicate the positive mineralogical identification of carbonates through cathodoluminescent techniques alone (Marfunin,
1979; Machel, 1985; Machel and Burton, 1991; Gaft et al., 2005), but corroboration of the chemical composition of BMS using SEM-EDS indicates that luminescence mapping may be a useful proxy. SEM-EDS analyses indicate the presence of $\mathrm{Ca}, \mathrm{Mg}$, and $\mathrm{Fe}$ ions within BMS, substantiating the inductive inference that these mineral inclusions are a species of disordered ferrous dolomite.

Biomimetic Features of Cell Wall Microstructure.-Scalalike protrusions are present within the intercellular spaces of phloem cells, and aspects of their morphology superficially resemble filamentous bacteria or fungi. Comparison with microanatomy of extant plants (e.g., Carr and Carr, 1975), however, indicates instead that these features represent intercellular pectic protuberances (IPP). Variously termed pectic filaments, thickenings, scala, strands, and projections, IPP have been noted in the intercellular spaces of eudicots, monocots, and pteridophytes (Carlquist, 1956; Carr and Carr, 1975; Potgieter and van Wyk, 1992; Veys et al., 1999; Leroux et al., 2007). IPP are composed predominantly of polysaccharides rich in galacturonic acid and in some ferns, may also contain proteins and callose (Veys et al., 1999; Leroux et al., 2007). They are generally thought to form from middle lamella pectins during the expansion of cells, but may also be laid down later, sometimes in response to stress or wounding (Carlquist, 1956; Carr and Carr, 1975; Potgieter and van Wyk, 1992). The structures observed between phloem cells of Botryopteris (Fig. 5) mark the first identification of IPP in a fossil fern; however, similar structures were figured by Williamson and Scott (1894, figs. 31 A-C) in Calamites, and a reinvestigation of other Carboniferous fossils is likely to yield further examples.

The IPP between Botryopteris phloem cells do differ from the pectic scalae of extant ferns in two respects (Carr and Carr, 1975). First, the regular, scalalike IPP observed in Botryopteris are slightly larger in diameter than those described in other plants (Carr and Carr, 1975; Potgieter and van Wyk, 1992), and secondly, individual strands are sometimes terminated by spheroidal masses reminiscent of BMS seen elsewhere in the specimen (c.f. Figs. 1H, 5C). The difference in size likely resulted from mineral nucleation upon the original pectin strands (i.e., Fig. 5B, inset), and the spheroidal to subbotryoidal masses that occur on some strands appear morphologically congruent with disordered dolomite that has been synthesized in the presence of sulfides (Zhang et al., 2010).

Processes of Authigenic Mineralization.-Many common sulfate, silicate, and carbonate minerals can be precipitated in the presence of organic polymers, or as a result of biological processes. The production of authigenic minerals strictly through abiogenic processes is termed organomineralization, while biologically mediated mineral precipitation is identified as biomineralization (Trichet and Defarge, 1995). These processes differ in that organomineralization encompasses mineral precipitation in the presence of carbonaceous polymers, whereas biomineralization occurs in the presence of living cells (Trichet and Defarge, 1995). Biomineralization is subdivided into mineral formation that is either directly controlled, as in the case of magnetite crystals formed within magnetotactic, microaerophilic bacteria (Bazylinski, 1996), or passively induced, which may occur by mineral nucleation on microbial surfaces or extracellular polymeric substances (e.g., Ferris et al., 1987; Thompson and Ferris, 1990; Fortin et al., 1997; Léveillé et al., 2000; Van Lith et al., 2003), or by metabolic processes that alter local hydrochemistry permitting stoichiometric precipitation (Lovley and Phillips, 1986; Lovley et al., 1987; Roh et al., 2003; Straub et al., 2004). Biomimetic carbonates within Botryopteris may have resulted from a combination of both organomineralization and passive biomineralization.

Although many minerals passively nucleate on microbiogenic surfaces, most can also be precipitated through strictly abiogenic processes, including a number of biomimetic carbonates (Reitner, 2004). Humification reactions have been implicated in abiotic precipitation of rhodochrosite, $\mathrm{MnCO}_{3}$, (Hardie et al., 2009), and 
biomimetic crystals have been experimentally grown in aqueous solutions containing pectin, cellulose ethers, and xanthan (Butler et al., 2009; Zhang et al., 2009, Yang and Xu, 2011), and on Langmuir monolayers of stearic acid (Chen et al., 2009). As noted by Smoot and Taylor (1983), the Carboniferous BMS are restricted to phloem cells of Botryopteris tridentata (see Fig. 1A), which may indicate that similar soluble organic polymers played a role in mineral nucleation. Similarly, SEM-EDS analyses suggest the presence of carbonate minerals in association with plant cell walls, and components of the cell wall microstructure (the intercellular pectic protuberances) appear to have been nucleation sites for authigenic minerals.

While organomineralization processes may have contributed to permineralization of cell walls, microbial contribution to authigenic mineral formation is implicit in the presence of $\mathrm{Mg}^{2+}$-rich carbonates that form biomimetic structures, as naturally occurring dolomite is known to readily form at low temperatures only in the presence of microbial activity (Vasconcelos et al., 1995; Wright and Wacey, 2004). Bacteriogenic dolomites typically have a distinctive dumbbell-shaped morphology (e.g., Warthmann et al., 2000; Van Lith et al., 2003) similar to some of the spheroidal BMS and the spheroidal masses associated with some IPP. Dolomite is most often, although not exclusively, formed by microbes employing anaerobic sulfate reduction (Warthman et al., 2000; Roberts et al., 2004; Wright and Wacey, 2005; SánchezRomán et al., 2008). The occurrence of pyrite (Fig. 4) within the Botryopteris petiole provides additional evidence for the presence of anaerobic sulfate reduction, as euhedral pyrite grains like those present within Botryopteris are considered evidence for early diagenetic mineralization resulting from the metabolic activities of sulfatereducing bacteria (Grimes et al., 2002; McKay and Longstaffe, 2002). These pyrite crystals are encrusted with amorphous Mg-enriched carbonates, indicating that mineralization throughout the plant tissue was protracted, and likely progressed through several stages.

We hypothesize that early diagenesis mineralization of the decaying Botryopteris tissues began in an anoxic setting, where the metabolic activities of anaerobic sulfate-reducing bacteria facilitated stoichiometric precipitation of disordered ferrous dolomite; soluble organic polymers derived from humic reactions of phloem tissue may have functioned as initial mineral nuclei. Local changes in pore-water chemistry resulting from sulfate reduction may also have favored the precipitation of $\mathrm{Mg}^{2+}$-enriched carbonates along cell walls, the microstructural components of which appear to have acted as nucleation sites. As bacterial proliferation declined, calcium carbonate precipitation was favored, filling cell lumens and intercellular spaces. Thus, individual permineralized plants may be microcosms of the concretions within which they are preserved, as the formation of Carboniferous coal balls is suggested to have occurred in multiple stages (Scott and Rex, 1985; Scott et al., 1996; Diettrich et al., 2000, 2001; Boyce et al., 2001; Scott and Collinson, 2003).

Comprehensive investigation of the stages and processes involved in microscale mineralization necessitates an understanding that degrading plant substrates constitute highly localized chemical environments, resulting from combinations of pore-water chemistry, temperature, substrate composition, and the interactions within and among saprotrophic assemblages. Such microbial assemblages are themselves influenced by these extrinsic environmental factors, in addition to oxygen and metal cation availability (Eriksson et al., 1990; Jenkins and Suberkropp, 1995; Robertson et al., 2000; Zhou et al., 2002; Kravachenko and Sirin, 2007). Characterizing the microbial paleoecology of fossil plant substrates, then, is an obvious first step in understanding early diagenetic processes at the tissue level, as the activities of saprotrophic organisms were intimately tied to the chemical regimes under which mineralization occurred.

Chytridiomycete Fossils Indicate Diversity of Saprotrophic Assemblage.-Of the many saprotrophic organisms identified in modern rhizospheres, fungi, like bacteria, are ubiquitous agents of biodegradation and nutrient cycling (Goodfellow, 1983; Newell, 1996; Dighton et al., 2005). The association of legitimate microbial remains with degraded Botryopteris tissue indicates that the anaerobic degradation of these plant remains need not have been accomplished by sulfate-reducing bacteria alone, as some extant free-living chytrids also engage in anaerobic fermentation (Emerson and Natvig, 1981).

Although figured by Smoot and Taylor (1983), the unicells preserved within some Botryopteris cells were not attributed to a microbial group. Here, we interpret them as holocarpic, monocentric chytridiomycete zoosporangia. Although small, the size of these fossils accords with that of some other fossil chytridiomycete zoosporangia (Taylor et al., 1992; Krings et al., 2009a, 2009b). Traditional classifications of chytrids that employ morphological and developmental features of zoosporangia are known to be artificial, and these characters are acknowledged to be of little use in higher-level taxonomy (Blackwell et al., 2006; James et al., 2006b). The thallus is holocarpic, and the presence of an annular collar provides evidence that zoospores were released via an operculate discharge pore as in other monocentric chytrids, in which thallus development occurs through enlargement of an encysted zoospore (Beakes et al., 1992). We are unable to characterize aspects of zoospore development and morphology (i.e., flagellae), however, precluding further identification of the fossils at this time.

The external surfaces of the zoosporangia are covered by fine precipitates, which are continuous with those that occur on the surface of associated plant cell walls. As the zoosporangial walls of extant chytrids are typically smooth (Longcore, 1995), these precipitates are unlikely to reflect cell ornamentation, and we interpret them instead as authigenic minerals. As precipitates are less prevalent near the discharge pore, local mineralization probably commenced prior to removal of the operculum by zoospore discharge. As such, these fossils not only provide evidence for the diversity of microbes involved in the taphonomy of fossil plants, but demonstrate that some stages of mineralization were likely to have been synchronous with microbial proliferation.

Further Research.-Biomimetic structures similar to those examined in Botryopteris tridentata may be ubiquitous in permineralized plants. For instance, Rothwell and Taylor (1972) have noted small dark masses that are similar in size and arrangement to the BMS identified here, as have Andrews and Lenz (1943, fig. 6), who describe such structures as mycorrhizal haustoria. During this study, we reexamined these latter structures, and found that they are visually indistinguishable from those preserved in the phloem of Botryopteris. Similarly, material which has been identified as possible callose in a number of Carboniferous seed ferns, including Callistophyton boyssetii (Renault) Rothwell (1980), Schopfiastrum decussatum Andrews (1945), Medullosa pandurata Stewart (1951), and Callistophyton poroxyloides Delevoryas et Morgan (1954), may in fact be additional examples of bacteriogenic ferrous dolomite, and this possibility bears reinvestigation. Because many of these figured specimens were prepared as cellulose acetate peels, the use of monochromatic luminescence mapping may be preferable as a nondestructive alternative to SEM-EDS compositional analyses.

\section{CONCLUSIONS}

Expanding the known microbial fossil record in association with plant remains is essential to furthering our understanding of the diverse roles of microbes in ancient ecosystems, but as this study demonstrates, the biogenicity of putative body fossils must be definitively established, as early diagenetic processes can produce biomimetic pseudofossils. Inclusions within the phloem of a Carboniferous fern, Botryopteris tridentata, although originally interpreted as filamentous actinomycete bacteria, are in actuality disordered ferrous dolomites. The carbonate mineralogy of these inclusions was inferred from critical examination of morphology and monochromatic luminescence mapping, and was corroborated by SEM-EDS, which identified magnesium, calcium, and 
iron within the biomimetic structures. The precipitation of these structures within cell lumens is likely to have been biologically mediated by sulfate-reducing bacteria, and may also have involved organomineralization around nuclei of soluble organic polymers. The presence of similar mineral morphologies in association with intercellular pectic protuberances suggests that the chemical and biological regimes that resulted in the biomimetic structures also contributed to permineralization of the surrounding plant tissue.

Although we hypothesize that the metabolic activities of anaerobic sulfate-reducing bacteria were of primary importance in producing local hydrochemical environments favoring the precipitation of dolomite over calcite (and thereby contributing to the preservation of plant tissue), it should be noted that other microbial remains - to wit, uniporate cells which we interpret as holocapric chytridiomycete zoosporangia - are also present within these plant tissues. As such, the suite of anaerobic microorganisms involved in microbial preconditioning of plant tissues prior to, and concurrent with, the precipitation of authigenic minerals was likely to have been diverse. Further characterization of biomimetic carbonates in association with permineralized plants may provide insight into the microbial paleoecology of these ancient environments, by allowing more sophisticated inferences as to the metabolic strategies of associated fossil microbes. Such investigations are also likely to afford novel opportunities to characterize the hydrogeochemistry of early stages of diagenesis, thereby expanding our understanding of taphonomic controls and processes within the paleobotanical record.

\section{ACKNOWLEDGMENTS}

This research was supported in part by the National Science Foundation (EAR-0949947 to T.N.T. and M.K.; OPP-0943934 to E.L.T. and T.N.T.), and the Department of Ecology and Evolutionary Biology, University of Kansas. We thank Drs. Rudolph Serbet and Benjamin Bomfleur for productive discussions, and Heather Shinogle for technical assistance. Dr. Robert S. Capers, George Safford Torrey Herbarium, University of Connecticut, provided access to the material from the HN Andrews collection, for which we are appreciative. Two referees provided helpful commentary that substantially improved the manuscript.

\section{REFERENCES}

Abràmoff, M.D., Magalhães, P.J., and Ram, S.J., 2004, Image processing with ImageJ: Biophotonics International, v. 11, p. 36-42.

Aliasgharzad, N., Mårtensson, L.M., and Ollson, P.A., 2010, Acidification of a sandy grassland favours bacteria and disfavours fungal saprotrophs as estimated by fatty acid profiling: Soil Biology and Biochemistry, v. 42, p. 1058-1064, doi: 10.1016/j.soilbio.2010.02.025.

Andrews, H.N., 1945, Contributions to our knowledge of American Carboniferous floras VII. Some pteridosperm stems from Iowa: Annals of the Missouri Botanical Garden, v. 32, p. 323-360, doi: 10.2307/2394379.

Andrews, H.N., and Lenz, L.W., 1943, A mycorrhizome from the Carboniferous of Illinois: Bulletin of the Torrey Botanical Club, v. 70, p. 120-135, doi: 10.2307/ 2481363.

Barghoorn, E.S., and Schopf, J.W., 1966, Microorganisms three billion years old from the Precambrian of South Africa: Science, v. 152, p. 758-763, doi: 10.1126/ science.152.3723.758.

Barghoorn, E.S., and Tyler, S.A., 1965, Microorganisms from the Gunflint Chert: These structurally preserved Precambrian fossils from Ontario are the most ancient organisms known: Science, v. 147, p. 563-575, doi: 10.1126/science.147.3658.563.

Barr, D.J.S., 2001, Chytridiomycota, in McLaughlin, D.J., McLaughlin, E.G., and Lemke, P.A., eds., The Mycota, vol. 7A: Springer-Verlag, New York, p. 93-112.

Bateman, R.M., Crane, P.R., DiMichele, W.A., Kenrick, P.R., Rowe, N.P., and Stern, W.E., 1998, Early evolution of land plants: Phylogeny, physiology, and ecology of the primary terrestrial radiation: Annual Review of Ecology and Systematics, v. 29, p. 263-292, doi: 10.1146/annurev.ecolsys.29.1.263.

BAZYLINKSI, D.A., 1996, Controlled biomineralization of magnetic minerals by magnetotactic bacteria: Chemical Geology, v. 132, p. 191-198, doi: 10.1016/S00092541(96)00055-1.
Beakes, G.W., Canter, H.A., and Jaworksi, G.H.M., 1992, Comparative ultrastructural ontogeny of zoosporangia of Zygorhizidium affluens and Z. planktonicum, chytrid parasites of the diatom Asterionella formosa: Mycological Research, v. 96, p. 1047-1059, doi: 10.1016/S0953-7562(09)80115-9.

Beimforde, C., Schäfer, N., Dörfelt, H., Nascimbene, P.C., Singh, H., Heinrichs, J., Reitner, J., Rana, R.S., and Schmidt, A.R., 2011, Ectomycorrhizas from a lower Eocene angiosperm forest: New Phytologist, v. 192, p. 988-996, doi: 10.1111/ j.1469-8137.2011.03868.x.

Bercovici, A., Hadley, A., and Villaneuva-Amadoz, U., 2009, Improving depth of field resolution for palynological photomicrography: Palaeontologica Electronica, v. 12, 3.2 MB, http://palaeo-electronica.org/2009_2/170/. Checked March 2012.

Bianciotto, V., Bandi, C., Minerdi, D., Sironi, M., Tichy, H.V., and Bonfante, P., 1996, An obligately endosymbiotic mycorrhizal fungus itself harbors obligately intracellular bacteria: Applied and Environmental Microbiology, v. 62, p. 30053010 .

Blackwell, W.H., Letcher, P.M., and Powell, M.J., 2006, Thallus development and the systematics of Chytridiomycota: An additional developmental pattern represented by Podochytrium: Mycotaxon, v. 97, p. 91-109.

Boggs, S., and Krinsley, D., 2006, Application of cathodoluminescence imaging to the study of sedimentary rocks: Cambridge University Press, New York, 165 p.

Bouwmeester, H.J., Roux, C., Lopez-Raez, J.A., and BéCard, G., 2007, Rhizosphere communication of plants, parasitic plants, and AM fungi: Trends in Plant Science, v. 12, p. 224-230, doi: 10.1016/j.tplants.2007.03.009.

Boyce, C.K., Aвrecht, M., Zhou, D., and Gilbert, P.U.P.A., 2010, X-ray photoelectron emission spectromicroscopic analysis of arborescent lycopsid cell wall composition and Carboniferous coal ball preservation: International Journal of Coal Geology, v. 83, p. 146-153, doi: 10.1016/j.coal.2009.10.008.

Brasier, M.D., Green, O.R., Lindsay, J.F., McLoughlin, N., Steele, A., and StoAkes, C., 2005, Critical testing of Earth's oldest putative fossil assemblage from the $\sim 3.5$ Ga Apex chert, Chinaman Creek, Western Australia: Precambrian Research, v. 140, p. 55-102, doi: 10.1016/j.precamres.2005.06.008.

Buick, R., 1990, Microfossil recognition in Archean rocks: An appraisal of spheroids and filaments from a 3500 m.y. old chert-barite unit at North Pole, Western Australia: PALAIOS, v. 5, p. 441-459, doi: 10.2307/3514837.

Butler, M.F., Frith, W.J., Rawlins, C., Weaver, A.C., and Heppenstall-Butler, M., 2009, Hollow calcium carbonate microsphere formation in the presence of biopolymers and additives: Crystal Growth \& Design, v. 9, p. 534-545, doi: $10.1021 / \mathrm{cg} 8008333$

CARlquist, S., 1956, On the occurrence of intercellular pectic warts in Compositae: American Journal of Botany, v. 43, p. 425-429, doi: 10.2307/2439019.

CARR, S.G.M., and CARR, D.J., 1975, Intercellular pectic strands in parenchyma: Studies of plant cell walls by scanning electron microscopy: Australian Journal of Botany, v. 23, p. 95-105, doi: 10.1071/BT9750095.

Chen, Y., XiaO, J., Wang, Z., and Yang, S., 2009, Observation of an amorphous calcium carbonate precursor on a stearic acid monolayer formed during the biomimetic mineralization of $\mathrm{CaCO}_{3}$ : Langmuir, v. 25, p. 1054-1059, doi: 10.1021/ la8029424.

Chesnut, D.R., 1996, Geologic framework for the coal-bearing rocks of the Central Appalachian Basin: International Journal of Coal Geology, v. 31, p. 55-66, doi: 10.1016/S0166-5162(96)00011-0.

Conn, V.M., Walker, A.R., and Franco, C.M.M., 2008, Endophytic actinobacteria induce defense pathways in Arabidopsis thaliana: Molecular Plant-Microbe Interactions, v. 21, p. 208-218, doi: 10.1094/MPMI-21-2-0208.

Delevoryas, T., and Morgan, J., 1954, A new pteridosperm from Upper Pennsylvanian deposits of North America: Palaeontographica B, v. 96, p. 12-23.

Dietrich, D., Frosch, G., Rörler, R., and MarX, G., 2000, Analytical X-ray microscopy on Psaronius sp.: A contribution to permineralization process studies: Microchimica Acta, v. 133, p. 279-283, doi: 10.1007/s006040070105.

Dietrich, D., Witke, K., Rößler, R., and MarX, G., 2001, Raman spectroscopy on Psaronius sp.: A contribution to the understanding of the permineralization process: Applied Surface Science, v. 179, p. 230-233, doi: 10.1016/S01694332(01)00284-7.

Dighton, J., White, J.F., and Peter, O., 2005, The Fungal Community: Its Organization and Role in the Ecosystem, 3rd ed.: CRC Press, Boca Raton, Florida, $960 \mathrm{p}$.

Doumbou, C.L., Hamby Salove, M.K., Crawford, D.L., and Beaulieu, C., 2001, Actinomycetes, promising tools to control plant diseases and to promote plant growth: Phytoprotection, v. 82, p. 85-102.

Dupraz, C., Reid, R.P., Braissant, O., Decho, A.W., Norman, R.S., and Visscher, P.T., 2009, Processes of carbonate precipitation in modern microbial mats: EarthScience Reviews, v. 96, p. 141-161, doi: 10.1016/j.earscirev.2008.10.005.

El Ali, A., Barbin, B., Calas, G., Cervelle, B., Ramseyer, K., and Bouroulec, J., 1993, $\mathrm{Mn}^{2+}$-activated luminescence in dolomite, calcite and magnesite: Quantitative determination of manganese and site distribution by EPR and CL spectroscopy: Chemical Geology, v. 103, p. 189-202, doi: 10.1016/00092541(93)90150-H. 
Embley, T.M., and Stackebrandt, E., 1994, The molecular phylogeny and systematics of the Actinomycetes: Annual Review of Microbiology, v. 48, p. 257-289, doi: 10.1146/annurev.micro.48.1.257.

Emerson, R., and Natvig, D.O., 1981, Adaptation of fungi to stagnant waters, in Wicklow, D.T., and Carroll, G.C., eds., The Fungal Community: Its Organization and Role in the Ecosystem: Marcel Dekker, New York, p. 109-128.

Eriksson, K.E.L., Blanchette, R.A., and Ander, P., 1990, Microbial and enzymatic degradation of wood and wood components: Springer-Verlag, New York, 407 p.

Ferris, F.G., Fyfe, W.S., and Beveridge, T.J., 1987, Bacteria as nucleation sites for authigenic minerals in a metal-contaminated lake sediment: Chemical Geology, v. 63, p. 225-232, doi: 10.1016/0009-2541(87)90165-3.

Fortin, D., Ferris, F.G., and Beveridge, T.J., 1997, Surface-mediated mineral development by bacteria, in Banfield, J.F., and Nealson, K.H., eds., Geomicrobiology: Interactions between microbes and minerals: Reviews in Mineralogy 35, Mineralogical Society of America, Washington, DC, p. 161-180.

Fostowicz-Frelik, L., and Frelik, G.J., 2010, Earliest record of dental pathogen discovered in a North American Eocene rabbit: PALAIOS, v. 25, p. 818-822, doi: 10.2110/palo.2010.p10-084r.

Fox, G. E., and Stackebrandt, E., 1987, The application of 16s rRNA cataloguing and $5 \mathrm{~s}$ rRNA sequencing in microbial systematics: Methods in Microbiology, v. 19, p. 405-458, doi: 10.1016/S0580-9517(08)70416-1.

Gaft, M., Reisfeld, R., and Panczer, G., 2005, Modern Luminescence Spectroscopy of Minerals and Materials: Springer, Berlin, $356 \mathrm{p}$.

GarcíA-RuIz, J.M., 1994, Inorganic self-organisation in Precambrian cherts: Origins of Life and Evolution of Biospheres, v. 24, p. 451-467, doi: 10.1007/BF01582030.

García-Ruiz, J.M., Carnerup, A., Christy, A.G., Welham, N.J., and Hyde, S.T., 2002, Morphology: An ambiguous indicator of biogenicity: Astrobiology, v. 2, p. 353-369, doi: 10.1089/153110702762027925.

García-ruiz, J.M., Hyde, S.T., Carnerup, A.M., Christy, A.G., Van Kranendonk, M.J., and Welham, N.J., 2003, Self-assembled silica-carbonate structures and detection of ancient microfossils: Science, v. 302, p. 1194-1197, doi: 10.1126/ science. 1090163.

García-Vallès, M., Fernández-Turiel, J.L., Gimeno-Torrente, D., SaavedraAlonso, J., and Martinez-Manent, S., 2008, Mineralogical characterization of silica sinters from the El Tatio geothermal field, Chile: American Mineralogist, v. 93, p. 1373-1383, doi: 10.2138/am.2008.2583

Girard, V., and AdL, S.M., 2011, Amber microfossils: On the validity of species concept: Comptes Rendues Palevol, v. 10, p. 189-200, doi: 10.1016/j.crpv. 2010.11.002.

Gleason, F. H., Kagami, M., Lefrevre, E., and Sime-Ngando, T., 2008, The ecology of chytrids in aquatic ecosystems: Roles in food web dynamics: Fungal Biology Reviews, v. 22, p. 17-25, doi: 10.1016/j.fbr.2008.02.001.

Goodfellow, M., 1983, Ecology of Actinomycetes: Annual Review of Microbiology, v. 37, p. 189-216, doi: 10.1146/annurev.mi.37.100183.001201.

Gorobets, B.S., and Rogojine, A.A., 2002, Luminescent Spectra of Minerals: RCP VIMS, Moscow, $300 \mathrm{p}$.

Götze, J., 2002, Potential of cathodoluminescence (CL) microscopy and spectroscopy for the analysis of minerals and materials: Analytical and Bioanalytical Chemistry, v. 374 , p. $703-708$.

Greb, S.F., Hiett, J.K., Weisenfluh, G.A., Andrews, R.E., and Sergeant, R.E., 1999, Geology of the Fire Clay Coal in part of the Eastern Kentucky Coal Field: Kentucky Geological Survey, Report of Investigations ser. 12, no. 2, p. 1-37.

Grimes, S.T., Davies, K.L., Butler, I.B., Brock, F., Edwards, D., Rickard, D., Briggs, D.E.G., and Parkes, R.J., 2002, Fossil plants from the Eocene London Clay: The use of pyrite textures to determine the mechanism of pyritization: Journal of the Geological Society, v. 159, p. 493-501, doi: 10.1144/0016-764901176.

Grotzinger, J.P., and Rothman, D.H., 1996, An abiotic model for stromatolite morphogenesis: Nature, v. 383, p. 423-425, doi: 10.1038/383423a0.

Hardie, A.G., Dynes, J.J., KozaK, L.M., and Huang, P.M., 2009, Biomoleculeinduced carbonate genesis in abiotic formation of humic substances in nature: Canadian Journal of Soil Science, v. 89, p. 445-453, doi: 10.4141/cjss08074.

Harper, C.J., Bomfleur, B., Decombeix, A.L., Taylor, E.L., Taylor, T.N., and Krings, M., 2012, Tylosis formation and fungal interactions in an Early Jurassic conifer from northern Victoria Land, Antarctica: Review of Palaeobotany and Palynology, v. 175, p. 25-31, doi: 10.1016/j.revpalbo.2012.02.006.

Hibbett, D.S., Binder, M., Bischoff, J.F., Blackwell, M., Cannon, P.F., Eriksson, O.E., Huhndorf, S., James, T., Kirk, P.M., Lucking, R., Thorsten Lumbsch, H., Lutzoni, F., Matheny, P.B., Mclaughlin, D.J., Powell, M.J., Redhead, S., Schoch, C.L., Spatafora, J.W., Stalpers, J.A., Vilgalys, R., Aime, M.C., Aptroot, A., Bauer, R., Begerow, D., Benny, G.L., Castlebury, L.A., Crous, P.W., Dai, Y.-C., Gams, W., Geiser, D.M., Griffith, G.W., Gueidan, C., Hawksworth, D.L., Hestmark, G., Hosaka, K., Humber, R.A., Hyde, K.D., Ironside, J.E., Kölualg, U., Kurtzman, C.P., Larsson, K.-H., Lichtwardt, R., Longcore, J., Miadlikowska, J., Miller, A., Moncalvo, J.M., MozleyStandridge, S., Oberwinkler, F., Parmasto, E., Reeb, V., Rogers, J.D., Roux,
C., Ryvarden, L., Sampaio, J.P., Schübler, A., Sugiyama, J., Thorn, R.G., Tibell, L., Untereiner, W.A., Walker, C., Wang, Z., Weir, A., Weib, M., White, M.M., WinKA, K., YaO, Y.J., and Zhang, N., 2007, A higher-level phylogenetic classification of the Fungi: Mycological Research, v. 111, p. 509-547, doi: 10.1016/ j.mycres.2007.03.004.

Hofmann, H.J., 1972, Precambrian remains in Canada: Fossils, dubiofossils, and pseudofossils: Proceedings of the International Geological Congress, 24th Session, Montreal, sect. 1, p. 20-30

Hunter-Ceverja, C., and Eveleigh, D.E., 1990, Actinomycetes, in Dindal, D.L., ed., Soil Biology Guide: John Wiley and Sons, New York, p. 3348.

Jaatinen, K., Laiho, R., Vuorenmaa, A., Castillo, U.D., Minkkinen, K., Pennanen, T., Penttilä, T., and Fritze, H., 2008, Responses of aerobic microbial communities and soil respiration to water-level drawdown in a northern boreal fen: Environmental Microbiology, v. 10, p. 339-353, doi: 10.1111/j.1462-2920. 2007.01455.x.

James, T.Y., Kauff, F., Schoch, C.L., Matheny, P.B., Hofstetter, V., Cox, C.J., Celio, G., Gueidan, C., Fraker, E., Miadlikowska, J., Lumbsch, H.T., Rauhut, A., Reeb, V., Arnold, A.E., Аmtoft, A., Stajich, J.E., Hosaka, K., Sung, G.-H., Johnson, D., O’Rourke, B., Crockett, M., Binder, M., Curtis, J.M., Slot, J.C., Wang, Z., Wilson, A.W., Schübler, A., Longcore, J.E., O’Donnell, K., MozleyStandridge, S., Porter, D., Letcher, P.M., Powell, M.J., Taylor, J.W., White, M.M., Griffith, G.W., Davies, D.R., Humber, R.A., Morton, J.B., Sugiyama, J., Rossman, A.Y., Rogers, J.D., Pfister, D.H., Hewitt, D., Hansen, K., Hambleton, S., Shoemaker, R.A., Kohlmeyer, J., Volkmann-Kohlmeyer, B., Spotts, R.A., Serdani, M., Crous, P.W., Hughes, K.W., Matsuura, K., Langer, E., Langer, G., Untereiner, W.A., Lücking, R., Büdel, B., Geiser, D.M., Aptroot, A., Diederich, P., Schmitt, I., Schultz, M., Yahr, R., Hibbett, D.S., Lutzoni, F., Mclaughlin, D.J., Spatafora, J.W., and Vilgalys, R., 2006a, Reconstruction the early evolution of fungi using a six-gene phylogeny: Nature, v. 443, p. 818-822, doi: 10.1038/nature05110.

James, T.Y., Letcher, P.M., Longcore, J.E., Mozley-Standridge, S.E., Porter, D., Powell, M.J., Griffith, G.W., and Vilgalys, R., 2006b, A molecular phylogeny of the flagellated fungi (Chytridiomycota) and description of a new phylum (Blastocladiomycota): Mycologia, v. 98, p. 860-871, doi: 10.3852/mycologia. 98.6.860.

Jenkins, C.C., and Suberkropp, K., 1995, The influence of water chemistry on the enzymatic degradation of leaves in streams: Freshwater Biology, v. 33, p. 245-253, doi: $10.1111 / \mathrm{j} .1365-2427.1995 . t b 01165 . x$.

Joy, K.W., Willis A.J., and LACEY W.S., 1956, A rapid cellulose peel technique in palaeobotany: Annals of Botany, v. 20, p. 635-637.

Karling, J.S., 1977, Chytriomycetarum Iconographia: J. Cramer, Vadus, Lichtenstein; Lubrecht \& Cramer, Monticello, New York, 414 p.

Kilpatrick, A.M., Briggs, C.J., and DaszaK, P., 2010, The ecology and impact of chytridiomycosis: An emerging disease of amphibians: Trends in Ecology and Evolution, v. 25, p. 109-118, doi: 10.1016/j.tree.2009.07.011

Knoll, A.H., 1982, Microfossils from the late Precambrian Draken Conglomerate, Ny Friesland, Svalbard: Journal of Paleontology, v. 56, p. 755-790.

Kotsyurbenko, O.R., Chin, K.J., Glagolev, M.V., Stubner, S., Simankova, M.V., Nozhevnikova, A.N., and Conrad, R., 2004, Acetoclastic and hydrogenotrophic methane production and methanogenic populations in an acidic West-Siberian peat bog: Environmental Microbiology, v. 6, p. 1159-1173, doi: 10.1111/j.14622920.2004.00634.x.

Kravachenko, I.K., and Sirin, A.A., 2007, Activity and metabolic regulation of methane production in deep peat profiles of boreal bogs: Microbiology, v. 76, p. 791-798, doi: 10.1134/S0026261707060203.

Krings, M., Galtier, J., Taylor, T.N., and Dotzler, N., 2009a, Chytrid-like microfungi in Biscalitheca cf. musata (Zygopteridales) from the Upper Pennsylvanian Grand-Croix cherts (Saint-Etienne Basin, France): Review of Palaeobotany and Palynology, v. 157, p. 309-316, doi: 10.1016/j.revpalbo.2009.06.001.

Krings, M., Dotzler, N., Galtier, J., and Taylor, T.N., 2009b, Microfungi from the upper Visean (Mississippian) of central France: Chytridiomycota and chytridlike remains of uncertain affinity: Review of Palaeobotany and Palynology, v. 156, p. 319-328, doi: 10.1016/j.revpalbo.2009.03.011.

Krings, M., Taylor, T.N., Taylor, E.L., Dotzler, N., and Walker, C., 2011, Arbuscular mycorrhizal-like fungi in Carboniferous arborescent lycopsids: New Phytologist, v. 191, p. 311-314, doi: 10.1111/j.1469-8137.2011.03752.x.

Krings, M., Taylor, T.N., and Dotzler, N., 2012, Fungal endophytes as a driving force in land plant evolution: Evidence from the fossil record, in Southworth, D., eds., Biocomplexity of Plant-Fungal Interactions: John Wiley \& Sons, Inc., New York, p. 5-28.

Lalonde, S.V., Konhauser, K.O., Reysenbach, A.-L., and Ferris, F.G., 2005, The experimental silicification of Aquificales and their role in hot spring sinter formation: Geobiology, v. 3, p. 41-52, doi: 10.1111/j.1472-4669.2005.00042.x.

Lawton, P., Whitaker, A., Odell, D., and Stowell, J.D., 1989, Actinomycete morphology in shaken culture: Canadian Journal of Microbiology, v. 35, p. 881889, doi: 10.1139/m89-147. 
Lechevalier, H.A., and Lechevalier, M.P., 1967, Biology of actinomycetes: Annual Review of Microbiology, v. 21, p. 71-100, doi: 10.1146/annurev.mi.21.100167. 000443.

Leroux, O., Knox, J.P., Leroux, F., Vrijdaghs, A., Bellefroid, E., Borgonie, G., and VIANE, R.L., 2007, Intercellular pectic protuberances in Asplenium: New data on their composition and origin: Annals of Botany, v. 100, p. 1165-1173, doi: 10.1093/aob/mcm 210 .

LÉveillé, R.J., Fyfe, W.S., and LongstafFe, F.J., 2000, Geomicrobiology of carbonate-silicate microbialites from Hawaiian basaltic sea caves: Chemical Geology, v. 169, p. 339-355, doi: 10.1016/S0009-2541(00)00213-8.

Lodwig, E.M., Hosie, A.H.F., Bourdès, A., Findlay, K., Allaway, D., KarunaKaran, R., Downie, J.A., and Poole, P.S., 2003, Amino-acid cycling drives nitrogen fixation in the legume-Rhizobium symbiosis: Nature, v. 422, p. 722-726, doi: 10.1038/nature01527.

LONGCORE, J.E., 1995, Morphology and zoospore ultrastructure of Entophlyctis luteolus sp. nov. (Chytridiales): Implications for chytrid taxonomy: Mycologia, v. 87 , p. 25-33, doi: 10.2307/3760942.

Lovley, D.R., and Phillips, E.J.P., 1986, Organic matter mineralization with reduction of ferric iron in anaerobic sediments: A review: Applied Environmental Microbiology, v. 51, p. 683-689, doi: 10.1080/01490458709385975.

Lovley, D.R., Stolz, J.F., Nord, G.L., and Phillips, E.J.P., 1987, Anaerobic production of magnetite by a dissimilatory iron-reducing microorganism: Nature, v. 330, p. 252-254, doi: 10.1038/330252a0.

Lowe, D.R., 1994, Abiological origin of described stromatolites older than $3.2 \mathrm{Ga}$ : Geology, v. 22, p. 387-390, doi: 10.1130/0091-7613(1994)022<0387:AOODSO > 2.3.CO;2

Machel, H.G., 1985, Cathodoluminescence in calcite and dolomite and its chemical interpretation: Geoscience Canada, v. 12, p. 139-147.

Machel, H.G., and Burton, E.A., 1991, Factors governing cathodoluminescence in calcite and dolomite, and their implications for studies of carbonate diagenesis: Luminescence Microscopy and Spectroscopy, SEPM (Society of Economic Paleontologists and Mineralogists) Short Course Notes, v. 25, p. 37-57.

Marfunin, A.S., 1979, Spectroscopy, Luminescence, and Radiation Centers in Minerals: Springer-Verlag, Berlin, $352 \mathrm{p}$.

Massini, J.G., Channing, A., Guido, D.M., and Zamuner, A.B., 2012, First report of fungi and fungus-like organisms from mesozoic hot springs: PALAIOS, v. 27, p. 55-62, doi: 10.2110/palo.2011.p11-076r.

McKay, J.L., and Longstaffe, F.J., 2002, Sulphur isotope geochemistry of pyrite from the Upper Cretaceous Marshybank Formation, Western Interior Basin: Sedimentary Geology, v. 157, p. 175-195, doi: 10.1016/S0037-0738(02)00233-6.

McLoughlin, N., Wilson, L.A., and Brasier, M.D., 2008, Growth of synthetic stromatolites and wrinkle structures in the absence of microbes: Implications for the early fossil record: Geobiology, v. 6, p. 95-105, doi: 10.1111/j.1472-4669. 2007.00141.x.

McRae, C.M., and Wilson, N.C., 2008, Luminescence database I: Minerals and materials: Microscopy and Microanalysis, v. 14, p. 184-204, doi: 10.1017/ S143192760808029X.

Millay, M., and TaYlor, T.N., 1978, Chytrid-like fossils of Pennsylvanian age: Science, v. 200, p. 1147-1149, doi: 10.1126/science.200.4346.1147.

NewELL, S.Y., 1996, Established and potential impacts of eukaryotic mycelial decomposers in marine/terrestrial ecotones: Journal of Experimental Marine Biology and Ecology, v. 200, p. 187-206, doi: 10.1016/S0022-0981(96)02643-3.

Pirozynski, K.A., and Malloch, D.W., 1975, The origin of land plants: A matter of mycotrophism: BioSystems, v. 6, p. 153-164, doi: 10.1016/0303-2647(75)90023-4.

PoInar, G., JR., 2011, Paleorhodococcus dominicanus n. gen., n. sp. (Actinobacteria) in a faecal droplet of Triatoma dominicana (Hemiptera: Reduviidae: Triatominae) in Dominican amber: Historical Biology, v. 24, p. 1-3, doi: 10.1080 / 08912963.2011.615931.

Potgieter, M.J., and VAN WYK, A.E., 1992, Intercellular pectic protuberances in plants: Their structure and taxonomic significance: Botanical Bulletin of Academia Sinica, v. 33, p. 295-316.

Powell, M. J., 1993, Looking at mycology with a Janus face: A glimpse at Chytridiomycetes active in the environment: Mycologia, v. 85, p. 1-20, doi: $10.2307 / 3760471$.

Reddell, P., and Bowen, G.D., 1985, Frankia source affects growth, nodulation, and nitrogen fixation in Casuarina species: New Phytologist, v. 100, p. 115-122, doi: 10.1111/j.1469-8137.1985.tb02763.x.

ReITNER, J., 2004, Organomineralization: A clue to the understanding of meteoriterelated 'bacteria-shaped' carbonate particles, in Seckbach, J., ed., Origins: Genesis, Evolution and Diversity of Life: Kluwer Academic Publishers, Dordrecht, p. 197212, doi: 10.1007/1-4020-2522-X 13.

Roberts, J.A., Bennett, P.C., GonzÁlez, L.A., Macpherson, G.L., and Miliken, K.L., 2004, Microbial precipitation of dolomite in methanogenic groundwater: Geology, v. 82, p. 277-280, doi: 10.1130/G20246.2.

Robertson, S.M.C., Hornung, M., and Kennedy, V.H., 2000, Water chemistry of throughfall and soil water under four tree species at Gisburn, northwest England, before and after felling: Forest Ecology and Management, v. 129, p. 101-117, doi: 10.1016/S0378-1127(99)00156-5

Roh, Y., Zhang, C.-L., Vali, H., Lauf, R.J., Zhou, J., and Phelps, T.J., 2003, Biogeochemical and environmental factors in Fe biomineralization: Magnetite and siderite formation: Clays and Clay Minerals, v. 51, p. 83-95, doi: 10.1346/ CCMN.2003.510110.

Rothwell, G. W., 1980, The Callistophytaceae (Pteridospennopsida). II. Reproductive features. Palaeontographica B, v. 173, p. 85-106, doi: 10.2307/2441482.

Rothwell, G.W., and TaYlor, T.N., 1972, Carboniferous pteridosperm studies: Morphology and anatomy of Schopfiastrum decussatum: Canadian Journal of Botany, v. 50, p. 2649-2658.

Saint Martin, S., Saint Martin, J.-P., Girard, V., Grosheny, D., and Néraudeau, D., 2012, Filamentous micro-organisms in Upper Cretaceous amber (Martigues, France): Cretaceous Research, v. 35, p. 217-229, doi: 10.1016/j.cretres.2012.01.003.

Sánchez-román, M., Vasconcelos, C., Schmid, T., Dittrich, M., McKenzie, J.A., Zenobi, R., and Rivadeneyra, M.A., 2008, Aerobic microbial dolomite at the nanometer scale: Implications for the geologic record: Geology, v. 36, p. 879-882, doi: $10.1130 / \mathrm{G} 25013 \mathrm{~A} .1$

SCHOPF, J.M., 1961, Coal-ball occurrences in eastern Kentucky: United States Geological Survey Professional Paper, v. 95, p. B228-B230.

Schopf, J.W., 1993, Microfossils of the early Archean Apex Chert: New evidence of the antiquity of life: Science, v. 260, p. 640-646, doi: 10.1126/science.260.5108.640.

Schopf, J.W., 2004, Earth's earliest biosphere: Status of the hunt, in Eriksson, P.G., Altermann, W., Nelson, D.R., Mueller, W.U., and Catuneanu, O., eds., The Precambrian Earth: Tempos and Events: Elsevier, Amsterdam, p. 516-539.

Scott, A.C., and Collinson, M.E., 2003, Non-destructive multiple approaches to interpret the preservation of plant fossils: Implications for calcium-rich permineralizations: Journal of the Geological Society, v. 160, p. 857-862, doi: 10.1144/0016$764902-163$.

Scott, A.C., and Rex, G., 1985, The formation and significance of Carboniferous coal balls: Philosophical Transactions of the Royal Society of London, B, v. 311, p. 123-137, doi: 10.1098/rstb.1985.0144.

Scott, A.C., Mattey, D.P., and Howard, R., 1996, New data on the formation of Carboniferous coal balls: Review of Palaeobotany and Palynology, v. 93, p. 317 331, doi: 10.1016/0034-6667(95)00132-8.

Sellstedt, A., Huss-Danell, K., and Ahlqvist, A.-S., 1986, Nitrogen fixation and biomass production in symbioses between Alnus incana and Frankia strains with different hydrogen metabolism: Physiologia Plantarum, v. 66, p. 99-107, doi: 10.1111/j.1399-3054.1986.tb01240.x.

Sмоот, E.L., 1979, The phloem of Etapteris leclercqii and Botryopteris tridentata: American Journal of Botany, v. 66, p. 511-521, doi: 10.2307/2442500.

Sмоot, E.L., and TAYlor, T.N., 1983, Filamentous microorganisms from the Carboniferous of North America: Canadian Journal of Botany, v. 61, p. 22512256, doi: 10.1139/b83-245.

Stackebrandt, E., and Woese, C.R., 1981, Towards a phylogeny of the actinomycetes and related organisms: Current Microbiology, v. 5, p. 197-202, doi: $10.1007 / \mathrm{BF} 01571146$

Stackebrandt, E., Rainey, F.A., and Ward-Rainey, N.L., 1997, Proposal for a new hierarchic classification system, Actinobacteria classis nov.: International Journal of Systematic Bacteriology, v. 47, p. 479-491, doi: 10.1099/00207713-47-2-479.

Stewart, W.N., 1951, Medullosa pandurata sp. nov. from the McLeansboro Group of Illinois: American Journal of Botany, v. 38, p. 709-717, doi: 10.2307/2437918.

Straub, K.L., Schünhuber, W.A., Buchholz-Cleven, B.E.E., and Schink, B., 2004, Diversity of ferrous iron-oxidizing, nitrate-reducing bacteria and their involvement in oxygen-independent iron cycling: Geomicrobiology Journal, v. 21, p. 371-378, doi: 10.1080/01490450490485854.

Taechowisan, T., Peberdy, J.F., and Lumyong, S., 2003, Isolation of endophytic actinomycetes from selected plants and their antifungal activity: World Journal of Microbiology \& Biotechnology, v. 19, p. 381-385, doi: 10.1023/A:1023901107182.

TAYloR, T.N., and Krings, M., 2010, Paleomycology: The rediscovery of the obvious: PALAIOS, v. 25, p. 283-286, doi: 10.2110/palo.2010.S03.

Taylor, T.N., Remy, W., and Hass, H., 1992, Fungi from the Lower Devonian Rhynie chert: Chytridiomycetes: American Journal of Botany, v. 79, p. 1233-1241, doi: $10.2307 / 2445050$

Thompson, J.B., and Ferris, F.G., 1990, Cyanobacterial precipitation of gypsum, calcite, and magnesite from natural alkaline lake water: Geology, v. 18, p. 995-998, doi: 10.1130/0091-7613(1990)018<0995:CPOGCA > 2.3.CO;2.

Tomescu, A.M.F., Rothwell, G.W., and Honegger, R., 2006, Cyanobacteria macrophytes in an early Silurian (Llandovery) continental biota: Passage Creek, lower Massanutten Sandstone, Virginia, USA: Lethaia, v. 39, p. 329-338, doi: $10.1080 / 00241160600876719$

Trewin, N., Fayers, S., and Kelman, R., 2003, Subaqueous silicification of the contents of small ponds in an Early Devonian hot-spring complex, Rhynie, Scotland: Canadian Journal of Earth Sciences, v. 40, p. 1697-1712, doi: 10.1139/ e03-065. 
Trichet, J., and Defarge, C., 1995, Non-biologically supported organomineralization: Bulletin de l'Institut Oceanographique Monaco, v. 14, p. 203-236.

Van Lith, Y., Warthmann, R., Vasconcelos, C., and McKenzie, J.A., 2003, Microbial fossilization in carbonate sediments: A result of the bacterial surface involvement in dolomite precipitation: Sedimentology, v. 50, p. 237-245, doi: 10.1046/j.1365-3091.2003.00550.x.

Van Zuilen, M.A., Lepland, A., and Arrhenius, G., 2002, Reassessing the evidence for the earliest traces of life: Nature, v. 418, p. 627-630, doi: 10.1038/nature00934.

Vasconcelos, C., McKenzie, J.A., Bernasconi, S., Grujic, D., and Tien, A.J., 1995, Microbial mediation as a possible mechanism for natural dolomite formation at low temperatures: Nature, v. 377, p. 220-222, doi: 10.1038/377220a0.

Ventura, M., Canchaya, C., Tauch, A., Chandra, G., Fitzgerald, G.F., Chater, K.F., and van Sinderen, D., 2007, Genomics of Actinobacteria: Tracing the evolutionary history of an ancient phylum: Microbiology and Molecular Biology Reviews, v. 71, p. 495-548, doi: 10.1128/MMBR.00005-07.

Veys, P., Waterkeyn, L., Lejeune, A., and Van Hove, C., 1999, The pore of the leaf cavity of Azolla: Morphology, cytochemistry and possible functions: Symbiosis, v. 27 , p. $33-57$.

Wacey, D., Kilburn, M.R., Saunders, M., Cliff, J., and Brasier, M.D., 2011, Microfossils of sulphur-metabolizing cells in 3.4-billion-year-old rocks of Western Australia: Nature Geoscience, v. 4, p. 698-702, doi: 10.1038/ngeo1238.

WAGGONER, B., 1993, Fossil actinomycetes and other bacteria in Eocene amber from Washington State, USA: Tertiary Research, v. 14, p. 155-160.

WAGGoner, B.M., 1994a, Fossil actinomycete in Eocene-Oligocene Dominican amber: Journal of Paleontology, v. 68, p. 398-401.

WAGGONER, B.M., 1994b, Fossil microorganisms from Upper Cretaceous amber of Mississippi: Review of Palaeobotany and Palynology, v. 80, p. 75-84, doi: 10.1016/ 0034-6667(94)90094-9.

Waksman, S.A., 1950, The Actinomycetes: Their Nature, Occurrence, Activities, and Importance: Chronica Botanica Company, Waltham, Massachusetts, $230 \mathrm{p}$.

Wang, B., Yeun, L.H., Xue, J.-H., Liu, Y., Ané, J.M., and Qiu, Y.-L., 2010, Presence of three mycorrhizal genes in the common ancestor of land plants suggests a key role of mycorrhizas in the colonization of land by plants: New Phytologist, v. 186 , p. 514-525, doi: 10.1111/j.1469-8137.2009.03137.x.

Warthmann, R., van Lith, Y., Vasconcelos, C., McKenzie, J.A., and Karpoff, A.M., 2000, Bacterially induced dolomite precipitation in anoxic culture experiments: Geology, v. 28, p. 1091-1094, doi: 10.1130/0091-7613(2000)028 $<$ 1091:BIDPIA $>2.3$. CO 2 .
Waychunus, G.A., 1988, Luminescence, X-ray emission and new spectroscopies, in Hawthorne, F.C., eds., Spectroscopic Methods in Mineralogy and Geology: Reviews in Mineralogy, v. 18, p. 639-688.

Wilkinson, H.P., 2003, Fossil actinomycete filaments and fungal hyphae in dicotyledonous wood from the Eocene London Clay, Isle-of-Sheppey, Kent, England: Botanical Journal of Linnean Society, v. 142, p. 383-394, doi: 10.1046/ j.1095-8339.2003.00179.x

Williamson, W.C., and Scott, D.H., 1894, Further observations of the organization of the fossil plants of the Coal-Measures: Part I. Calamites, Calamostachys, and Sphenophyllum: Philosophical Transactions of the Royal Society, London, B, v. 185 , p. 863-959, doi: 10.1098/rstb.1894.0019.

Wright, D.T., and WACEY, D., 2004, Sedimentary dolomite: A reality check: Geological Society, London, Special Publications, v. 235, p. 65-74, doi: 10.1144/ GSL.SP.2004.235.01.03.

Wright, D.T., and WACEY, D., 2005, Precipitation of dolomite using sulphatereducing bacteria from the Coorong Region, South Australia: Significance and implications: Sedimentology, v. 52, p. 987-1008, doi: 10.1111/j.1365-3091. 2005.00732.x.

YANG, X., and Xu, G., 2011, The influence of xanthan on the crystallization of calcium carbonate: Journal of Crystal Growth, v. 314, p. 231-238, doi: 10.1016/j. jcrysgro.2010.11.158.

Zhang, F., YANG, X., and Tian, F., 2009, Calcium carbonate growth in the presence of water soluble cellulose ethers: Materials Science and Engineering C, v. 29, p. 2530-2538, doi: 10.1016/j.msec.2009.08.001.

Zhang, F., Xu, H., Konishi, H., and Roden, E.E., 2010, A relationship between $d_{104}$ value and composition in the calcite-disordered dolomite solid-solution series: American Mineralogist, v. 95, p. 1650-1656, doi: 10.2138/am.2010.3414

Zhi, X.Y., Li, W.J., and Stackebrandt, E., 2009, An update of the structure and 16S rRNA gene sequence-based definition of higher ranks of the class Actinobacteria, with the proposal of two new suborders and four new families and emended descriptions of the existing higher taxa: International Journal of Systematic and Evolutionary Microbiology, v. 59, p. 589-608, doi: 10.1099/ijs.0.65780-0.

Zhou, J., Xia, B., Treves, D.S., Wu, L.-Y., Marsh, T.L., O’Neill, R.V., Palumbo, A.V., and Tiedje, J.M., 2002, Spatial and resource factors influencing high microbial diversity in soil: Applied and Environmental Microbiology, v. 68, p. 328334, doi: 10.1128/AEM.68.1.326-334.2002.

ACCEPTED DECEMBER 2, 2012 